\title{
Energy Management Practices In an Autoancillery to Reduce Carbon Footprint for Environmentally Sustainable Manufacturing
}

\author{
Bansal Deepak ${ }^{1,2}$, Yadav Nidhi $^{1}$, Bagan Munish ${ }^{1}$, Narsi R. Bishnoi ${ }^{2}$, \\ Sharma Mona ${ }^{3 *}$ \\ ${ }^{1}$ JBM Group, Gurgaon, Haryana, India \\ ${ }^{2}$ Department of Environmental Science \& Engineering, Guru Jambheshwar University of Science \& \\ Technology, Hisar, Haryana, India \\ ${ }^{*}$ Department of Environmental Sciences, Central University of Haryana, Mahendergarh, Haryana, India \\ *Email:drmonasharmal@gmail.com
}

\begin{abstract}
In the era of extreme global competition the industries are more focusing on adoption of latest and advanced technology and sustainable manufacturing practices. These days manufacturing is also viewed from broader perspective of sustainability, therefore, manufacturing companies are also pushing them to achieve various dimensions of sustainability, such as social, economical and environmental. Industries are regularly working on reducing their carbon footprint. Energy management is one of the method through which industries are focusing on reduction of carbon footprint and cost to become more sustainable in this competitive time. Regular cost reduction pressure on auto component manufacturing company from their Original Equipment Manufacturer (OEM) is increasing day by day due to competition in market. To compensate the pressure auto-component manufacturing industries are taking many initiatives. Apart from raw material and manpower cost, energy cost is also one of the major contributors. Due to carbon footprint the role of energy management has greatly expanded. Major industries are contracting with energy service providers to implement energy management practices to improve efficiency. The present study aims to identify the energy management practices adopted by an auto ancillary to reduce its carbon footprint for environmentally sustainable manufacturing.
\end{abstract}

Keywords: Energy management, Auto ancillary, Carbon footprint, Sustainable manufacturing.

\section{INTRODUCTION}

Energy is an essential input for manufacturing processes and plays a very critical role for economic growth of a country. In India, industrial sector contributes $45 \%$ of energy consumption followed by domestic (22\%) and agriculture (18\%) (CEA, 2015). Footprint can help users for better understanding of energy distribution in every industry and to compare use, loss, and carbon emissions within and across sectors. Areas of high energy consumption or significant energy losses indicate opportunities to improve efficiency by implementing energy management best practices, upgrading energy systems, or developing new technologies (MECS, 2010). To meet the energy requirements, India is focusing on the production of energy. As per the $12^{\text {th }}$ Five year plan of Planning Commission of India, the domestic energy production in 2016-17 will be 669.6 million tonnes of oil equivalent (MTOE). Which will be further increased to 844 MTOE in 2021-22. As per the energy statistics data of 2016 by Ministry of Statistics and Programme Implementation, consumption of electricity has increased from 411887 GWh during
2005-06 to 948328 GWh during 2014-15 with a CAGR of $8.72 \%$. Consumption per Capita has increased upto 17731 Mega Jules in 2014-15 w.r.t. 12781 Mega Joules in 2005-06 with a CAGR of $3.3 \%$. Industrial share in electricity consumption is highest with $44.11 \%$ followed by domestic and agriculture sectors with 22.93 and $17.81 \%$, respectively Footprint can help users to better understand the distribution of energy use in each industry and to compare use, loss, and carbon emissions within and across sectors. Areas of high energy consumption or significant energy losses indicate opportunities to improve efficiency by implementing energy management best practices, upgrading energy systems, or developing new technologies. The footprint provides a macro-scale benchmark for evaluating the benefits of improving energy efficiency and for prioritizing opportunity analysis.

Automobile sector in India is growing with very fast rate. Production of automobile in India has increased from 13.4 Million units in 2011 to 18.8 Million units in 2016. As per Society of Indian Automobile Manufacturer (SIAM), Indian share to 
Global passenger vehicle market will increase from $2.40 \%$ to $8 \%$ in 2020 . Two wheeler segments India is the second largest two wheeler manufacturer of World, with expected growth of two wheeler manufacturing around 18.8 Million in year 2016 to around 34 Million in 2020. Similarly passenger vehicle production is expected to increase from 3.4 million in 2016 to 10 Million in 2020. Maruti Suzuki India Limited (MSIL) is the market leader in passenger car segment with market share of $46 \%$ followed by Tata Motors with $16.5 \%$. Hyundai Motors India Ltd. is on third level with about $14 \%$. Others companies like Mahindra \& Mahindra, Honda Cars India, Toyota Kirloskar Motor Pvt. Ltd, Ford India Pvt. Ltd., General Motors, Skoda, Force Motors, Fiat, and Hindustan Motors, account for the remaining share (Auto Car Professionalhttp://www.autocarpro.in/news-

national/tata-motors-dharwad-plant-bags-nationalenergy-conservation-award-2016-22988).

As per Inter Governmental Panel on Climate Change (IPCC), carbon dioxide contributing $76 \%$ of total green house gas emission followed by methane and Nitrous oxide. Major source $\mathrm{CO}_{2}$ emission is burning of fossil fuels. Economic sector wise green house gas emission is mainly due to Electricity and Heat production $(25 \%)$ followed by Agriculture, Forestry and other land use (24\%) and Industry (21\%). Emission contribution due to usage of electricity is not covered in the data. Some sustainability initiatives in manufacturing practices taken by Maruti Udyog Ltd. Maruti Udyog Ltd took some steps forward to make its products sustainable as these products of automobile industry touch daily lives by providing personal mobility for millions. Maruti Udyog, India's leading automaker whose parent is Suzuki from Japan, has also paved its way towards sustainable development by incremental changes in few things that resulted in big savings. Maruti has reduced its electricity consumption per vehicle by $20 \%$ in the last nine years, water consumption by $46 \%$, and land fill waste by $67 \%$. The carbon dioxide emission has declined $27 \%$ in seven years. It has become a zero discharge company

\section{ENERGY MANAGEMENT PRACTICES}

Various energy management practices adopted by the company are listed below:

\subsection{Energy Management Cell (EMC)}

The company has established one Energy Management Cell at Corporate Level. The major responsibility of this cell includes following:

a) Identification of energy saving projects across the manufacturing locations. and recycles all its water (Kumar et al., 2011). Tata Motors Dharwad Plant has also taken many initiatives to reduce the consumption of energy. Through various initiatives they have reduced $12 \%$ Energy consumed during FY 2014-15 w.r.t FY 201314. The company has constantly focused on energy generation, utilization, conversion, storage, transmission, conservation, management and sustainability, by working on several projects to improve operational efficiency. They are also awarded First Level for National Energy Conservation Awards in the Automobile Sector for 2015 and 2016 by Bureau of Energy Efficiency (Auto Car Professional, 2016). Hyundai Motors is monitoring the energy consumption per unit of vehicle produced. Energy consumed per vehicle (MWh/Vehicle) has reduced from 1.10 in 2013 to 1.07 in 2015. To improve the response towards Emission Trading Scheme Hyundai has established the GHG Emission Management Council to address GHG-related issues. Through this consultative channel, the company has examined its GHG emission reduction program and performances. As a result of this Green House Gas Emission per unit of vehicle produced $\left(\mathrm{tCO}_{2} \mathrm{Eq} /\right.$ Vehicle) has reduced from 0.521 in 2014 to 0.519 in 2015 (Hyndai Sustainability Report -2016). To achieve the environmental sustainability in business, Toyota motors has set "Toyota Environmental Challenge 2050" which focus on Zero Carbon Emission, minimizing and optimizing water usages and Recycling based system. Zero Carbon emission challenge will focus on New Vehicle Zero $\mathrm{CO}_{2}$ Emissions, Life Cycle Zero $\mathrm{CO}_{2}$ Emissions and Plant Zero $\mathrm{CO}_{2}$ Emissions. (Toyota's Environmental Initiatives 2015). The present study was carried out in an auto ancillary, supplying parts to Maruti Suzuki India Limited to understand the various initiatives/management practices adopted by company to reduce its energy consumption as well as Carbon footprint for sustainable development. The footprint provides a macro-scale benchmark for evaluating the benefits of improving energy efficiency and for prioritizing opportunity analysis.

b) Facilitate plants for implementation of energy saving projects.

c) Scanning of new technology for energy saving

d) Monitoring of execution of energy saving projects

e) Monitoring of actual results of energy saving. of 
Energy management Cell has established the laboratory facility for monitoring and measurement of data related to energy. Laboratory has all necessary instruments required for the purpose of monitoring and measurements. Establishing dedicated lab for energy management inferred that top management has clear cut commitment towards energy saving and energy management.

\subsection{Management Commitment}

To make the energy management as an integral part of business, process wise energy consumption targets are set during starting of every financial year to improve energy efficiency. Every process owner develops detailed action plan to achieve the energy saving targets. These actions are short term and long term based on (payback period and type of technology). Department head of each process review the energy consumption on daily basis. Top management reviews the performance on energy saving on monthly basis through their Management Review Meeting (MRM).

\subsection{Environmental Management System}

The Company has implemented Environmental Management System based on the requirement of ISO 14001. Company is using PDCA Approach for ensuring the effectiveness of implemented system. Environmental aspects and their associated impacts of all activities are identified as per the defined methodology of the company (Deepak et al., 2015). All the identified impacts are evaluated on various criteria like scale of impact, severity of impact, probability of occurrence of aspect, legal requirements, resource depletion and interested parties concern. Resource depletion in terms of energy consumption is monitored and significant impacts are identified. Continual improvement projects related to energy are identified and implemented based on the significant aspects. Performance Indicators like power consumption per unit of product is monitored

\subsection{Benchmarking of Process}

Energy consumption data is collected from similar processes and reviewed for adequacy and accuracy. As the process and operations involved in manufacturing include different product type and high volume and variability as well as machines with technological differences, therefore internal specific energy consumption benchmarks have been established to monitor and review KPIs. In case of utilities such as pumps, chillers and air compressors along with air dryers, the specific energy consumption norms are considered based upon the latest best available technology in the market. Processes are reviewed in-depth to identify the areas of improvements. After analysis of processes key actions/activities are identified and implemented to improve the performance of the existing processes.

\subsection{Employee Involvement}

Involvement of people definitely helps the organization to reduce the energy consumption by minimizing or elimination of energy losses. The organization has taken many initiatives to motivate and involve the employees for energy saving. Few examples are given below:

a) Recognition of individual person for identifying and implementing Kaizen related to energy through kaizen scheme.

b) Celebration of Energy Conservation week

c) Energy Quiz

d) Red Tag campaign to identify the air leakage points in compressed air distribution system

\subsection{Awareness among Employees}

Awareness of employees play very vital role in energy saving. Regular training and awareness make them sensitized to identify the losses of energy. Few mechanisms adopted by company to make people aware are below:
a) Internal and external training on energy conservation
b) Daily/Weekly Review and Communication
c) Display of energy saving Posters and Slogans

\subsection{Energy Auditing}

Energy auditing is a structured approach to identify the energy saving potential in various processes. Re-audit is required to validate the actual saving achieved versus plan. The organization is doing regular audits to identify the potential and actual energy savings from various processes.

\section{Carbon Footprint}

Carbon footprint of two major products calculated based on Scope 01 and Scope 02 Methodology. During the base year 2012-13 Carbon Footprint (CFP) of product 01 and Product 02 was observed as 1.24 and $5.095 \mathrm{~kg}$ of $\mathrm{CO}_{2}$ per unit respectively. 


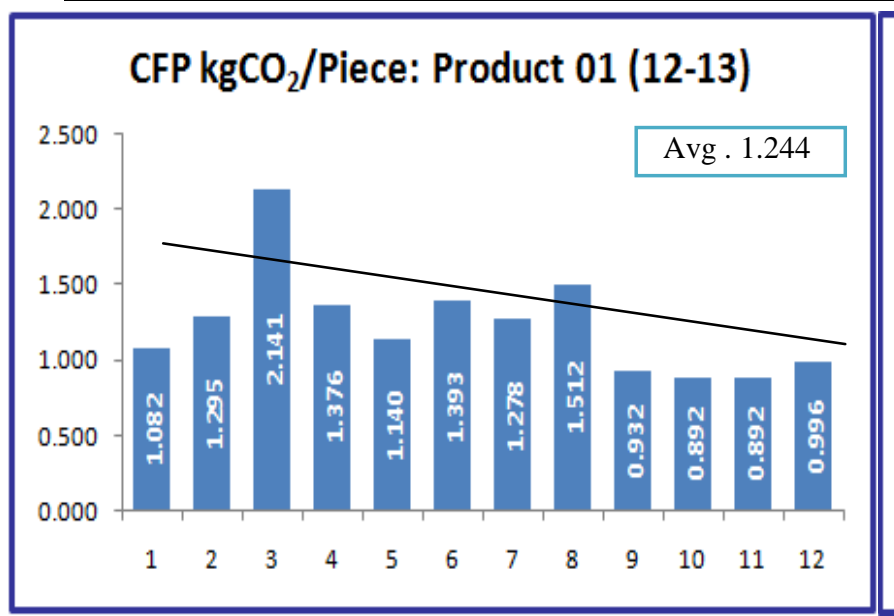

(A)

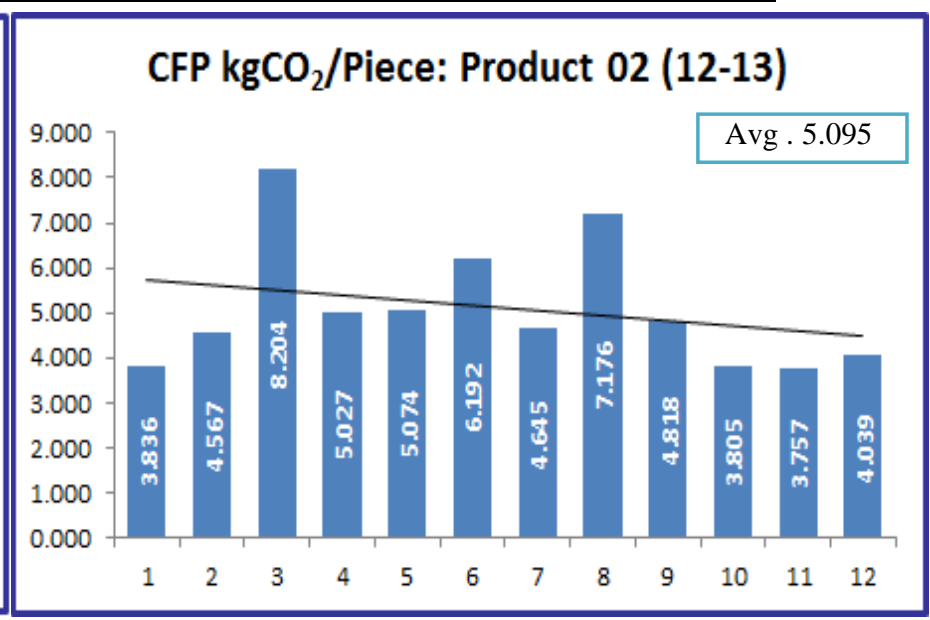

(B)

Fig. 1 (A-B). Contributor for CFP $\left(\mathrm{kg} \mathrm{CO}_{2}\right)$ for Product 01 and Product 02 in the year 2012-13

CFP for Product 01 and 02 has shown in Fig. 1 and Major contributor for CFP for Product 01 and Product 02 are shown in Fig. 2a and Fig. 2b, respectively. Electricity consumption is major contributor for both the products (Product 01 and Product 02).
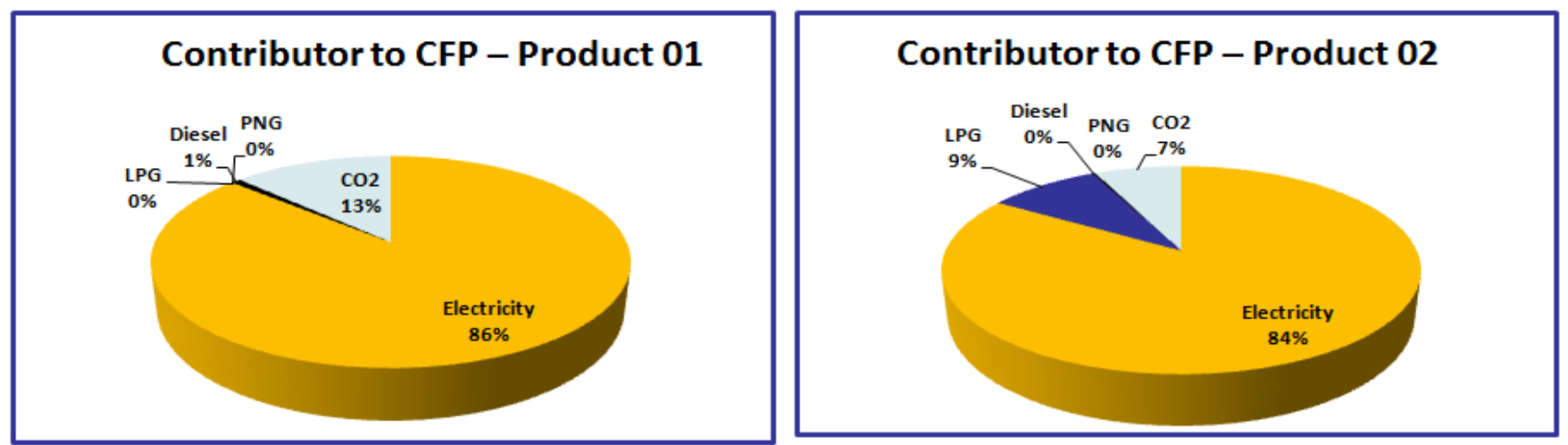

(A)

(B)

Fig. 2 (A-B). Contributors for carbon footprint (CFP) for Product 01 and Product 02

To reduce the electricity consumption further analysis of electricity consumption is carried out to identify the major processes to be focused for energy saving. Fig.3 shows the process wise electricity consumption data.

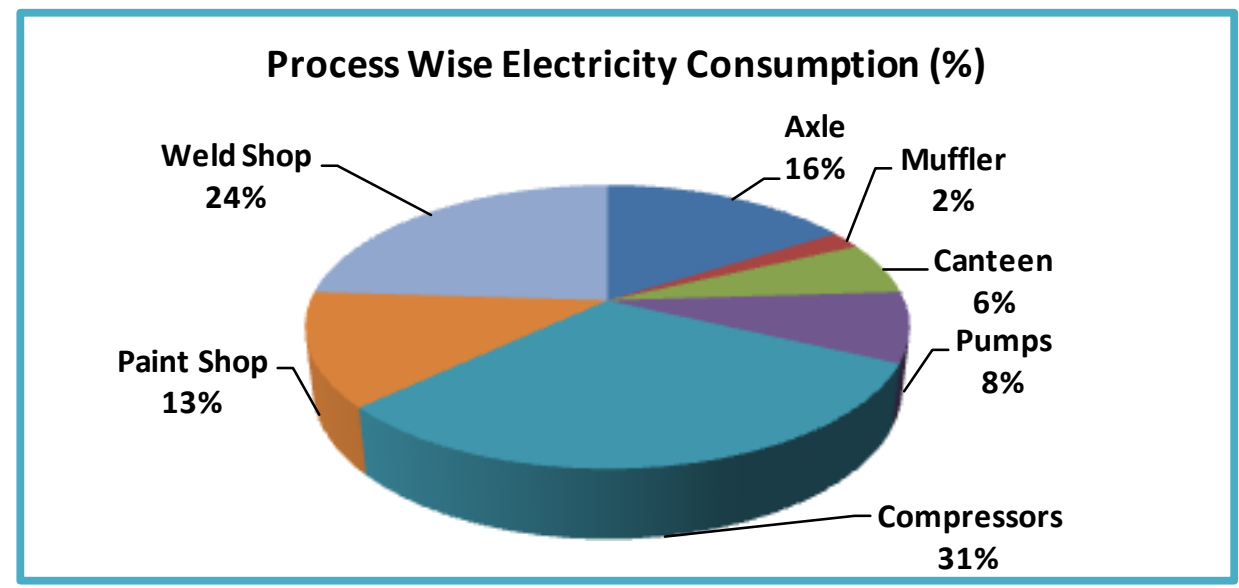

Fig. 3. Electricity consumption data by different processes 

ISSN : 2248-9622, Vol. 7, Issue 7, ( Part -2) July 2017, pp.20-25

After having analysis major focus area came out were compressors and pumps (Fig. 3). A list of major projects identified and implemented during the year of 2013-14 to 2016-17 are given in Table 1.

Table-1: List of major projects identified and implemented in the company

\begin{tabular}{|c|l|c|c|}
\hline Focus Area & \multicolumn{1}{|c|}{ Project } & $\begin{array}{c}\text { Actual Saving } \\
\text { kWh/Year }\end{array}$ & $\begin{array}{c}\text { Actual Saving } \\
\text { tCO }\end{array}$ per Year \\
\hline Lighting & Replacement of Conventional lights with LED. & $\mathbf{6 7 1 2 0}$ & $\mathbf{6 1 . 2 4}$ \\
\hline Compressor & Minimizing Air Leakage & $\mathbf{1 6 5 7 6 0}$ & $\mathbf{1 5 1 . 2 4}$ \\
\hline Water Pump & Cooling Water Line Modification & $\mathbf{6 6 0 0 0}$ & $\mathbf{6 0 . 2 2}$ \\
\hline Compressor & Replacement of Inefficient compressors. & $\mathbf{2 0 1 6 0 0}$ & $\mathbf{1 7 2 . 5 4}$ \\
\hline $\begin{array}{l}\text { Power Factor } \\
\text { Improvement }\end{array}$ & $\begin{array}{l}\text { Installation of Capacitor Bank for improving } \\
\text { Power Factor }\end{array}$ & $\mathbf{1 4 4 0 0}$ & $\mathbf{1 2 . 3 2}$ \\
\cline { 2 - 4 } & Harmonics mitigation through Harmonic Filters & $\mathbf{2 3 6 0 0}$ & $\mathbf{2 1 . 8 6}$ \\
\hline Paint Shop & Installation of VFDs & $\mathbf{6 3 0 0 0}$ & $\mathbf{5 8 . 3 4}$ \\
\cline { 2 - 4 } & Elimination of Idle losses of Pumps and Fans & $\mathbf{7 7 6 0}$ & $\mathbf{7 . 1 9}$ \\
\hline Cooling Tower & Replacement of Inefficient Cooling Tower & $\mathbf{6 7 5 8 0}$ & $\mathbf{5 3 . 4 9}$ \\
\hline Fans & Replacement of Fans & $\mathbf{3 3 9 1 7 0}$ & $\mathbf{2 6 8 . 4 4}$ \\
\hline & & $\mathbf{1 0 1 5 9 9 0}$ & $\mathbf{8 6 6 . 8 7}$ \\
\hline
\end{tabular}

There are total eight areas (utilization of lightening, compressor, water pump, compressor, power factor improvement, paint shop, cooling tower and fans) have been identified where energy consumption can be minimized (Table 1)

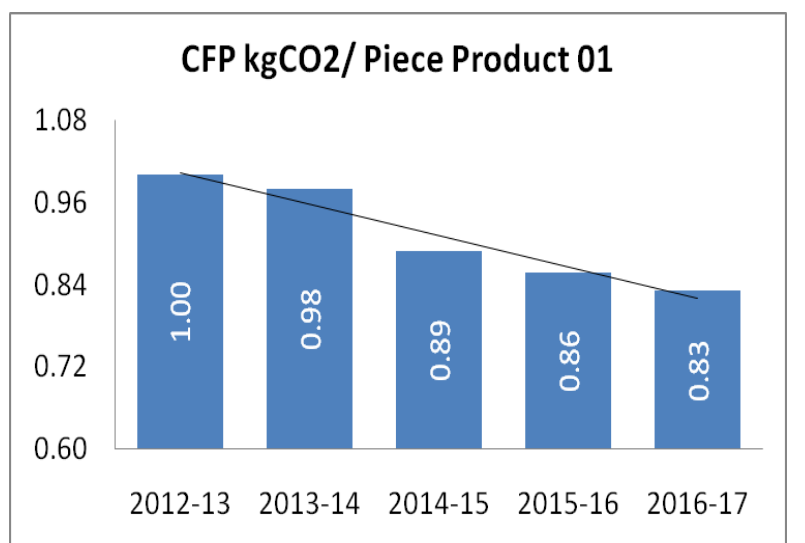

(A)
Implementation and monitoring of energy saving projects resulted in the reduction of Carbon Footprint of Product 01 and Product 02. Fig 04 shows the yearly carbon footprint trends for last five years, considering the base year carbon footprint as 01 .

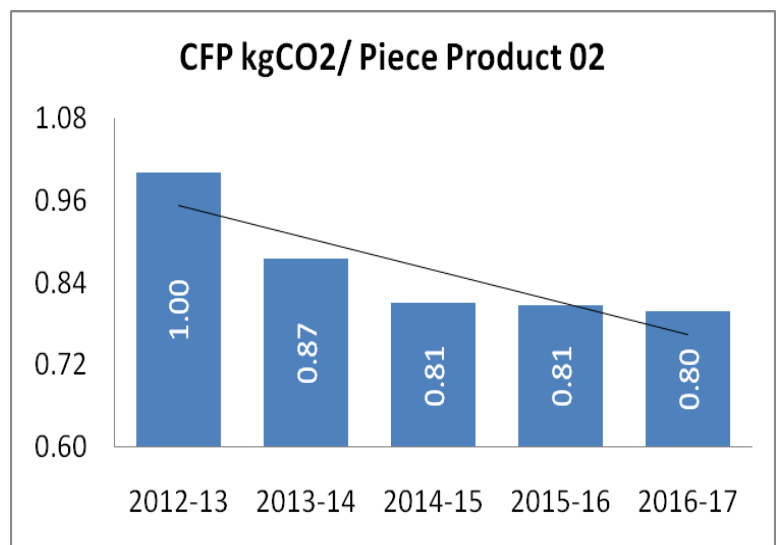

(B)

Fig. 4 (A-B). Carbon footprint (kg $\mathrm{CO}_{2}$ ) for Product 01 and Product 02 during 2012-13 to 2016-17

\section{CONCLUSION}

As a result of various energy management practices in the company a reduction in energy consumption has observed during last five years. The Company has implemented ten major projects for energy conservation, which has resulted into the saving of around $1015990 \mathrm{kWh}$. Overall Carbon footprint has reduced around $15.5 \%$ with respect to base year of 2012-13. Carbon footprint of major two products (Product 01 and Product 02) has shown reduction in
Carbon foot print per unit of product. During last five years CFP of Product 01 has reduced by $17 \%$ while of Product 02 has reduced by $20 \%$ w.r.t. base year CFP. Thus other auto ancillary having the same processes have the scope of reduction in energy consumption and to improve carbon footprint by adopting various energy management practices discussed in the paper. 
[1] Auto Car Professional http://www.autocarpro.in/news-national/tatamotors-dharwad-plant-bags-national-energyconservation-award-2016-22988

[2] Deepak, B., Bishnoi, N.R., Mona, S. (2015). Challenges and benefits of implementing an Environmental Management System: A review. International Journal of Advanced Scientific and Technical Research 5(2) 159-180.

[3] Energy Statistics, 2013 (Twentieth Issue), Central Statistics Office, Ministry of Statistics and Programme Implementation, Government of India.

[4] Energy Statistics, 2016, Central Statistics Office, Ministry of Statistics and Programme Implementation, Government of India. www.mospi.gov.in

[5] GHG Protocol Scope 2 Guidance. www.ghgprotocol.org

[6] http://HMC_Sustainability_Report_2012.pdf

[7] https://csr.hyundai.com/upfile/report/sar/Sustaina bility_Report (ENG)_2013.pdf

[8] Hyndai Sustainability Report -2016. https://www.unglobalcompact.org/participation/r eport/cop/create-and-submit/active/18712

[9] Kumar, V., Goyal, P., Rahman, Z., Kazmi, A.A. (2011). Sustainability Initiatives in Manufacturing: A case Study of Maruti Udyog Ltd. International Journal of Management and Business Study 2330-9519.

[10] MECS, 2010 https://energy.gov/eere/amo/manufacturingenergy-and-carbon-footprint-2010-mecs.

[11]Technical Guidance for Calculating Scope 3 Emissions

[12] Toyota's Environmental Initiatives 2015 (www.toyotaprensa.es/system/files_force/03_env ironmental_report15_fj_en.pdf) 